\title{
PENGATURAN PENANAMAN MODAL ASING DALAM BENTUK PERUSAHAAN JOINT VENTURE DI INDONESIA
}

\author{
Satria Sukananda. ${ }^{1}$ Wahyu Adi Mudiparwanto. ${ }^{2}$ \\ Kantor Wilayah Badan Pertanahan Nasional Provinsi Kepulauan Riau. ${ }^{1}$ \\ Jalan MT Haryono KM 3.5 No. 90, Tj Pinang Timur, Bukit Bestari, Kota Tj \\ Pinang, Kepulauan Riau, Indonesia. \\ Universitas Jendral Achmad Yani Yogyakarta. ${ }^{2}$ \\ J1. Ringroad Barat, Gamping Kidul, Ambarketawang, Sleman, Daerah Istimewa \\ Yogyakarta, Indonesia. \\ Email: artisukananda@gmail.com
}

\begin{abstract}
This study aims to analyze in depth about the foreign investment regulations in the form of a Joint Venture company in Indonesia and the obstacles faced in the implementation of Joint Ventures in Indonesia. Foreign investment is one of the main forms of international business transactions that are often needed. In many countries including Indonesia government regulations on foreign investment are in the form of joint venture requirements, namely the requirement that foreign investment must form a joint venture with local companies to carry out economic activities that are they want. This research uses a normative legal research method with a legislative approach that is studying various laws or jurisprudence and principles and related legal concepts. The results showed that foreign direct investment in Indonesia must be carried out in the form of the establishment of a joint venture company between foreign investors and national investors, as stipulated in Law Number 25 of 2007 concerning Investment. This joint venture company was established in the form of a Limited Liability Company, which is subject to Law Number 40 of 2007 concerning Limited Liability Companies. The provisions regarding the Negatif Investment List $(D N)$ are regulated in Presidential Regulation No.44 of 2016 relating to business fields that are open to requirements, one of which requires that it is associated with restrictions on foreign capital ownership. Therefore, the regulation indirectly requires foreign investors to partner with domestic investors by forming an enterprise or equity joint venture. Constraints faced by domestic investors with foreign investors in the form of joint ventures can be seen from three aspects including politics, law and economics.
\end{abstract}

Keywords : Regulation, Investment, Joint Venture.

\begin{abstract}
ABSTRAK
Penelitian ini bertujuan untuk menganalisa secara mendalam mengenai peraturan penanaman modal asing berbentuk perusahaan Joint Venture di Indonesia serta kendala yang dihadapi dalam pelaksanaan Joint Venture di Indonesia. Penanaman modal asing merupakan salah satu bentuk utama transaksi bisnis internasional yang sering dibutuhkan.. Di banyak negara termasuk Indonesia peraturan pemerintah tentang penanaman modal asing berbentuk persyaratan joint venture, yaitu persyaratan bahwa penanaman modal asing harus membentuk joint venture dengan perusahaan lokal untuk melaksanakan kegiatan ekonomi yang mereka inginkan. Penelitian ini menggunakan metode penelitian hukum normatif dengan pendekatan perundangan-undangan yakni mengkaji berbagai peraturan perundang-undangan atau yurisprudensi dan asas-asas serta
\end{abstract}

\footnotetext{
${ }^{1}$ Submission : 15 Oktober 2019 | Review-1 : 24 Januari 2020 | Production : 25 Januari 2020.
} 
konsep hukum terkait. Hasil penelitian menunjukan bahwa Penanaman modal asing secara langsung di Indonesia harus dilakukan dalam bentuk pendirian perusahaan joint venture antara investor asing dengan investor nasional, sebagaimana diatur dalam Undang-undang Nomor 25 Tahun 2007 tentang Penanaman Modal. Perusahaan joint venture ini didirikan dalam bentuk Perseroan Terbatas, yang tunduk kepada UndangUndang Nomor 40 Tahun 2007 tentang Perseroan Terbatas. Adapun ketentuan mengenai Daftar Negatif Investasi (DN) diatur dalam Peraturan Presiden No.44 Tahun 2016 yang berkaitan dengan bidang usaha yang terbuka dengan persyaratan, salah satunya mensyaratkan terkait dengan batasan kepemilikan modal asing. Dengan demikian secara tidak langsung ketentuan tersebut mewajibkan penanam modal asing untuk bermitra dengan penanam modal dalam negeri dengan membentuk joint venture enterprise atau equity joint venture. Kendala yang dihadapi oleh pemodal dalam negeri dengan penanam modal asing dalam bentuk joint venture dapat dilihat dari tiga aspek antara lain politik, hukum, dan ekonomi.

Kata kunci : Pengaturan, Penanaman Modal, Joint Venture.

\section{Pendahuluan}

Setiap negara selalu berusaha meningkatkan pembangunan, kesejahteraan dan kemakmuran rakyatnya. Usaha tersebut dilakukan dengan berbagai cara yang berbeda antara satu negara dengan negara lainnya. Salah satu usaha yang selalu dilakukan oleh negara adalah menarik sebanyak mungkin investasi asing masuk ke negaranya. ${ }^{2}$

Bagi Indonesia, masuknya modal asing merupakan tuntutan keadaan baik ekonomi maupun politik. Alternatif penghimpun dana pembangunan perekonomian Indonesia melalui investasi modal secara langsung jauh lebih baik dibandingkan dengan penarikan dana internasional lainnya seperti pinjaman luar negeri. ${ }^{3} \mathrm{Hal}$ ini dikarenakan selain menghasilkan devisa secara langsung bagi negara, kegiatan penanaman modal secara langsung menghasilkan manfaat yang sangat signifikan bagi negara tujuan penanaman modal (host country) karena sifatnya permanen/jangka panjang. ${ }^{4}$ Manfaat tersebut antara lain untuk mempercepat pembangunan ekonomi nasional, untuk mengolah potensi ekonomi menjadi kekuatan ekonomi riil dengan

\footnotetext{
${ }^{2}$ Ahmad Yulianto, "Peranana Multilateral Investment Guarantee Agency (MIGA) Dalam Kegiatan Investasi," Jurnal Hukum Bisnis 22, no. 5 (2003). hlm 39.

${ }^{3}$ Yulianto Syahyu, "Pertumbuhan Investasi Asing Di Kepalauan Batam: Antara Dualisme Kemimpinan Dan Ketidakpastian Hukum," Jurnal Hukum Bisnis 22, no. 5 (2003). hlm 46.

${ }^{4}$ Asmin Nasution, Transparansi Dalam Penanaman Modal (Medan: Pustaka Bangsa Press, 2008). hlm 1.
} 
menggunakan modal asing, untuk menciptakan lapangan kerja, dan lain sebagainya.

Kebutuhan akan modal asing ini diperlukan karena sumber pembiayaan negara dalam negeri (pajak, migas/nonmigas, bea masuk ekspor/impor, tabungan masyarakat) dan luar negeri (seperti pinjaman dan hibah) seringkali tidak cukup untuk pertumbuhan ekonomi maka diperlukan modal asing.

Landasan hukum penanaman modal di Indonesia diatur dalam berbagai peraturan perundang-undangan antara lain adalah Undang-Undang Nomor 1 Tahun 1967 jo Undang-Undang Nomor 6 Tahun 1968 jo Undang-Undang Nomor 12 Tahun 1970 tentang Penanaman Modal dalam Negeri (bisa disebut UUPMDN), kemudian diubah dengan Undang-Undang Nomor 25 Tahun 2007 tentang Penanaman Modal.

Dalam pelaksanaannya, terdapat berbagai peraturan pelaksanaan penanaman modal, di antaranya Peraturan Pemerintah Nomor 45 Tahun 2008 tentang Pedoman Pemberian Intensif dan Pemberian Kemudahan Penanaman Modal di Daerah, Peraturan Pemerintah Nomor 62 Tahun 2008 tentang Perubahan Atas Peraturan Pemerintah Nomor 1 Tahun 2007 tentang Fasilitas Pajak Penghasilan untuk Penanaman Modal di Bidang-Bidang Usaha Tertentu dan/atau Daerah-Daerah Tertentu, Peraturan Presiden Nomor 36 Tahun 2010 tentang Daftar Bidang Usaha yang Tertutup dan Bidang Usaha Yang Terbuka dengan Persyaratan di Bidang Penanaman Modal, Peraturan Presiden Nomor 90 Tahun 2007 tentang Badan Koordinasi Penanaman Modal, Peraturan Presiden Nomor 27 Tahun 2009 tentang Pelayanan Terpadu Satu Pintu di Bidang Penanaman Modal, dan lain sebagainya.

Penanaman modal asing merupakan salah satu bentuk utama transaksi bisnis internasional. Ada beberapa bentuk kerjasama antara penanaman modal asing dengan penanam modal dalam negeri yang dapat dilakukan seperti joint venture, joint enterpirse, production sharing contract, maupun bentuk kerjasama lainnya. Di banyak negara, peraturan pemerintah tentang penanaman modal asing berbentuk persyaratan joint venture, yaitu persyaratan bahwa penanaman modal asing harus membentuk joint venture dengan 
perusahaan lokal untuk melaksanakan kegiatan ekonomi yang mereka inginkan. ${ }^{5}$

Istilah joint venture dalam kehidupan masyarakat selalu dipergunakan untuk menunjukan suatu kerja sama dalam bidang-bidang tertentu yang melibatkan pihak asing di dalamnya. Di kalangan pemerintah, istilah joint venture adalah suatu istilah yang diberikan secara khusus untuk suatu bentuk kerja sama tertentu antara pemilik modal dalam negeri (swasta atau perusahaan negara) dan pemilik modal asing.

Menurut Sunaryati Hartono, bahwa sebenarnya istilah joint venture oleh para ahli yang berbahasa Inggris dipergunakan sebagai istilah verzamelnaam untuk berbagai bentuk kerja sama antara penanaman modal asing. Dengan pandangannya ini, menurutnya apa yang dikemukakan oleh Ismail Sunny dengan istilah joint enterprise juga merupakan salah satu bentuk joint venture. ${ }^{6}$ Dalam kepustakaan hukum, kerjasama ini disebut dengan perjanjian patungan atau kontrak joint venture.

Suatu kontrak joint venture atau kontrak usaha patungan adalah suatu upaya dari suatu kegiatan komersial (dengan risiko) oleh dua atau lebih pihak (yang bertindak) melalui suatu lembaga atau organisasi yang dibentuk untuk melaksanakan tujuan bersama. ${ }^{7}$ Peter Mahmud mengemukakan bahwa kontrak Joint Venture adalah suatu kontrak antara dua perusahaan untuk membentuk suatu perusahaan baru. Perusahaan baru inilah yang kemudian disebut joint venture company. ${ }^{8}$ Lebih lanjut, yang dimaksud dengan joint venture adalah suatu kerja sama antara pemilik modal asing dengan pemilik modal dalam negeri berdasarkan suatu perjanjian (kontraktual).

Mengingat pentingnya penanaman modal asing bagi perkembangan pembangunan ekonomi di Indonesia maka kajian mengenai pengaturan penanaman modal asing dalam bentuk perusahaan joint venture di Indonesia serta permasalahan yang dihadapi dalam pelaksanaanya menjadi penting

${ }^{5}$ John W. Head, Pengantar Umum Hukum Ekonomi (Jakarta: Proyek Elips, 1997). hlm 91

${ }^{6}$ Ismail Sunny, Tinjauan Dan Pembahasan Undang-Undang Penanaman Modal Asing Dan Kredit Luar Negeri (Jakarta: Pradnya Paramita, 1967). hlm 108 Hlm. 198

${ }^{7}$ Siti Anisah and Lucky Surya Wicaksono, Hukum Investasi (Yogyakarta: UII Press, 2017).

${ }^{8}$ Salim HS and Budi Sutrisno, Hukum Investasi Di Indonesia (Jakarta: Raja Grafindo Persada, 2012). Hlm. 206 
dilakukan. Karena tidak dipungkiri hukum berperan penting dalam menciptakan kesejahteraan dan pembangunan ekonomi. Pada era orde baru, para pakar ekonomi, pelaku ekonomi, dan penguasa memandang hukum sebagai penghambat bagi kelangsungan terselenggaranya kegiatan ekonomi. Hukum tidak dijadikan sebagai landasan, pemandu, dan penegak aktivitas dalam bidang ekonomi. Keberadaan hukum dirusak oleh penguasa hanya untuk membela kepentingan politik ekonomi Orde baru yang mengabdi pada kepentingan ekonomi negara-negara maju dan konglomerat serta Multi National Corporation (MNC). Namun setelah adanya krisis moneter yang meluluhlantahkan perkonomian beberapa negara diberbagai belahan dunia, mereka baru sadar akan arti pentingnya kewibawaan hukum untuk menciptakan iklim ekonomi yang kondusif dan untuk menarik investasi. ${ }^{9}$

Penelitian yang membahas tentang penanaman modal asing dan joint venture secara umum cukup banyak dilakukan oleh para peneliti terdahulu. Berdasarkan hasil penelusuran terhadap beberapa literatur yang telah dilakukan, maka setidaknya ditemukan beberapa literatur dalam bentuk jurnal yang membahas mengenai pengaturan penanaman modal asing. Pertama, Sayidin Abdullah dengan judul Politik Hukum penanaman Modal asing. Setelah berlakunya Undang-Undang Nomor 25 Tahun 2007 tentang Penanaman Modal dan Implikasinya Terhadap Pengusaha Kecil yang dilakukan dengan menggunakan metode kepustakaan (library research).

Kedua, I Gede Cahya Widiangga dan I Putu Sudarma Sumadi dengan judul Joint Venture Ditinjau dari Perspektif Undang- Undang Nomor 5 Tahun 1999 Tentang Larangan Praktek Monopoli dan Persaingan Usaha Tidak Sehat. Penelitian yang merupakan jenis penelitian normatif.

Berdasarkan kedua penelitian terdahulu tersebut di atas, maka dapat diketahui bahwa penelitian ini berbeda dengan penelitian tersebut. Adapun perbedaan tersebut terletak pada fokus kajian atau rumusan masalah yang ditawarkan karena penelitian ini memfokuskan kajian pada pengaturan

9 Adi Sulistiyono and Muhammad Rustamaji, Hukum Ekonomi Sebagai Panglima, (Sidoarjo: Mas Media Buana Pustaka, 2009). Hllm. 17 
penanaman modal asing berbentuk perusahaan joint venture di Indonesia serta kendala apa yang dihadapi dalam pelaksanaan joint venture di Indonesia.

\section{Rumusan Masalah}

Berdasarkan permasalahan yang telah dijelaskan di atas, maka batasan masalah dalam penelitian ini, yaitu bagaimanakah pengaturan penanaman modal asing berbentuk perusahaan joint venture di Indonesia serta kendala apa yang dihadapi dalam pelaksanaan joint venture di Indonesia.

\section{Tujuan Penelitian}

Untuk menganalisa pengaturan penanaman modal asing berbentuk perusahaan joint venture di Indonesia serta kendala yang dihadapi dalam pelaksanaan joint venture di Indonesia.

\section{Metode Penelitian}

Jenis penelitian ini merupakan penelitian hukum normatif dengan menggunakan studi kepustakaan yaitu penelitian hukum yang meletakkan hukum sebagai sebuah bangunan sistem norma. ${ }^{10}$ Adapun pencarian bahan didasarkan pada bahan hukum yang telah ada baik dalam bentuk peraturan perundangan-undangan maupun karya tulis seperti buku-buku ataupun artikel lain yang terdapat dalam situs internet yang relevan dengan objek penelitian ini. Penelitian hukum normatif ini digunakan untuk memahami pengaturan penanaman modal asing dalam bentuk perusahaan joint venture di Indonesia. Teknik pengumpulan data yang diperoleh dari bahan hukum primer dan bahan hukum sekunder akan dikaji dan ditelaah di dalam peraturan perundangundangan yang berhubungan dengan penelitian ini dan mempelajari hasil penelitian atau karya ilmiah orang lain dan buku-buku yang berisikan doktrindoktrin yang masih sesuai dengan penelitian ini kemudian mengumpulkan semua data yang diperlukan bagi penelitian ini.

\footnotetext{
${ }^{10}$ Mukti Fajar ND and Yulianto Achmad, Dualisme Penelitian Hukum Normatif \& Empiris (Yogyakarta: Pustaka Pelajar, 2010). Hlm. 34.
} 
Pendekatan penelitian ini adalah pendekatan perundang-undangan (statue approach). Pendekatan perundang-undangan dilakukan dengan mengkaji berbagai peraturan perundang-undangan atau yurisprudensi terkait isu hukum yang diteliti.

Bahan hukum dan bahan nonhukum yang diperoleh dalam penelitian ini akan dianalisis secara preskriptif dengan metode deduktif yaitu sebuah analisa yang menggunakaan penalaran atau proses berpikir yang bertolak dari kesimpulan khusus dari premis yang lebih umum. Jika premis benar dan cara penarikan kesimpulannya sah, maka dapat dipastikan hasil kesimpulannya benar. ${ }^{11}$ Sehingga data-data umum, asas-asas hukum, doktrin, dan peraturan perundang-undangan dirangkai secara sistematis sebagai susunan fakta-fakta hukum untuk mengkaji pengaturan penanaman modal asing dalam bentuk perusahaan joint venture di Indonesia.

\section{Hasil Penelitian dan Pembahasan}

\subsection{Pengaturan Penanaman Modal Asing Berbentuk Perusahaan Joint Venture di Indonesia}

Dalam Ensiklopedia Ekonomi Keuangan Perdagangan, joint venture diartikan sebagai suatu persetujuan antara dua perserta atau lebih, yang mempersatukan sumber-sumber jasa-jasanya, atau kedua-duanya, dalam satu perusahaan tertentu dengan tanpa membentuk suatu persekutuan yang tersusun. $^{12}$

Kemudian dalam Black's Law Dictionary dijelaskan bahwa joint venture adalah suatu badan hukum (legal entity) yang berwujud suatu perserikatan (in the nature of a partnership) yang diperjanjikan dalam usaha bersama sebagai suatu transaksi khusus dalam mencari kemanfaatan bersama. Suatu kumpulan dari beberapa orang yang secara bersama-sama menjalankan usaha komersial. Joint venture memerlukan persamaan kepentingan dalam menjalankan pokok urusan, adanya hak dan kewajiban

\footnotetext{
${ }^{11}$ Bandur and Agustinus, Penelitian Kualitatif Metodologi, Desain Dan Teknik Analisi Data Dengan NVIVO10 (Jakarta: Mitra Wacana Media, 2014). Hlm. 26

12 A. Abdurrachman, Ensiklopedia Tentang Konsep Ekonomi Keuangan Perdagangan (Jakarta: Pradnya Paramita, 1992). Hlm. 580
} 
untuk mengarahkan atau pengurusan dengan kebijakan tertentu, yang dapat diubah melalui perjanjian, untuk memperoleh keuntungan dan menanggung kerugian secara bersama-sama. ${ }^{13}$

Menurut George T. Framton dan Elvin R. Latty yang mengatakan: Joint Venture, Joint Adventure are terms used to denote something short of an "ordinary" partnership carrying on a continuing businesss. ${ }^{14}$ Maksudnya adalah joint venture adalah kerja sama sementara, yaitu suatu macam "partnership" (perserikatan) yang bersifat sementara.

Keberadaan perusahaan joint venture dalam penanaman modal asing secara umum mempunyai arti dan manfaat yang sangat besar bagi penanam modal dalam negeri maupun asing, yakni:

5.1.1. Pembatasan risiko dalam melakukan suatu kegiatan usaha yang sebenarnya penuh risiko. Dengan membentuk kerja sama maka risiko tersebut dapat disebarkan kepada para peserta.

5.1.2. Suatu pembiayaan melalui kerja sama untuk lebih mendayagunakan modal yang dilakukan dengan menyatukan modal yang dibutuhkan. ${ }^{15}$

Joint venture mampu menyatukan partner-partner yang usahanya tidak sejenis yang berasal dari dalam negara maupun luar negara, sehingga mampu mengoptimalkan know-how. Para pihak yang tidak sejenis usahanya mengadakan kerjasama sehingga dapat terjadi diverifikasi usaha. Ditambah lagi manfaat terhadap kemungkinan pembatasan kongkurensi atau saling keuntungan, apalagi terdapat kemudahan yang diberikan

\footnotetext{
${ }^{13}$ Lengkapnya, di dalam Black's Law Dictionary dinyatakan Joint venture adalah: legal entity in the nature of partnership engaged in the joint prosecution of a particular transaction for mutual profit. An association of persons jointly undertaking some commercial enterprise. It requires a community of interest in the perfomance of the subject matter, a right to direct or govern the policy in connection therewith, and duty, which may be altered by agreement, to share both in profit and losses."

${ }^{14}$ Sunny, Tinjauan Dan Pembahasan Undang-Undang Penanaman Modal Asing Dan Kredit Luar Negeri. Hlm. 107

${ }^{15} \mathrm{HS}$ and Sutrisno, Hukum Investasi Di Indonesia. Hlm. 207
} 
terhadap pihak penanaman modal asing mengadakan joint venture antara lain pembebasan bea materai dan kelonggaran di bidang pajak perseroan. ${ }^{16}$

Alasan pendirian kerjasama patungan atau joint venture tidak dapat dilepaskan dengan alasan penanaman modal asing secara umum di Indonesia. Bahkan dapat dikatakan bahwa kesepakatan pendirian perusahaan joint venture terlebih dahulu dilandasi alasan penanaman modal asing.

Erman Rajagukguk mengemukakan beberapa alasan mengapa para pihak, terutama pihak asing, mendirikan joint venture dalam melakukan investasi antara lain:

5.1.1. Pengusaha lokal telah berpengalaman dan menguasai pasar dalam negeri. Sebagai contoh investor asing bekerja sama dengan pengusaha tekstil lokal, karena pengusaha lokal tersebut telah mempunyai jaringan distribusi atau penjualan dan menguasai pasar lokal. Dengan demikian mereka tidak perlu lagi mengeluarkan biaya untuk membangun jaringan pemasaran.

5.1.2. Pengusaha lokal telah memliki sumber bahan baku. Sebagai contoh investor di bidang plywood mengajak pengusaha lokal yang mempunyai Hak Penguasaan Hutan (HPH), sehingga pasokan kayu untuk bahan baku plywood telah tersedia. Pengusaha asing juga mengajak pengusaha lokal untuk mendirikan joint venture, antara lain untuk menekan perasaan nasionalisme masyarakat lokal. Dengan memberikan kesempatan masyarakat lokal. Dengan memberikan kesempatan pengusaha lokal menjadi pemegang saham $10 \%$ misalnya, masyarakat lokal secara politis menganggap bahwa partisipasi dalam negeri sudah ada, sehingga ekonomi tidak seluruhnya dikuasai asing.

16 Supardji, Penanaman Modal Asing Di Indonesia (Jakarta: Universitas Al-Azhar Indonesia, 2008). Hlm. 71 
5.1.3. Untuk memudahkan hubungan dengan pemerintah dan masyarakat lokal. Hal tersebut terjadi karena partner lokal lebih mengenal sosial budaya masyarakat setempat. Begitu juga akan lebih mudah berhubungan dengan pemerintah setempat bila yang datang adalah pengusaha dalam negeri. ${ }^{17}$

Kemudian Supardji juga berpendapat bahwa penanaman modal asing melakukan joint venture dilakukan dengan pertimbangan antara lain:

\subsubsection{Untuk peningkatan modal}

Peningkatan modal dapat dilakukan antara lain melalui bentuk modal kerja ataupun modal investasi untuk mesinmesin dan peralatan-peralatan spareparts. Alasan ini dikarenakan bentuk joint venture adalah jenis usaha baru, jadi membawa modal baik yang berbentuk sebuah modal kerja maupun modal investasi.

\subsubsection{Transfer know-how}

Keahlian dan pengalaman di bidang processing dari barangbarang yang oleh penanaman modal dalam negeri yang selama ini hanya dikenal sebagai barang jadi. Di negaranegara berkembang belum cukup memiliki cukup keahlian dan teknologi untuk mengelola sumber daya yang tersedia menjadi suatu produk yang bernilai dan mempunyai nilai jual yang tinggi. Dengan demikian, para pengusaha dalam negeri dapat mempertahankan fungsi dagang dan pada akhirnya diharapkan mengambil alih fungsi-fungsi teknologi dari pihak investor asing pada suatu waktu tertentu.

\subsubsection{Jaring pemasaran}

Dengan joint venture penanaman modal asing dapat ikut serta dalam usaha mendapatkan saluran-saluran distribusi di daerah-daerah dimana jaringan-jaringan distribusi yang selama ini dikuasai oleh penanaman modal dalam negeri yang telah ada tidak dapat ditembus.

\footnotetext{
${ }^{17}$ Erman Rajaguguk, Indonesianisasi Saham (Jakarta: Bumi Aksara, 1985). Hlm. 66-68.
} 
5.1.4. Menjaga hubungan yang baik dengan pemerintah setempat.

Pemerintah setempat dapat membantu dengan memberikan kemudahan dalam usaha dan tidak menghambat berbagai proyek perusahaan. Kesempatan tersebut didukung dengan adanya kenyataan bahwa perusahaan lokal memiliki kelebihan untuk dapat mengatasi hambatan-hambatan dalam birokrasi dan lebih jauh dapat mempengaruhi birokrasi sesuai dengan tujuan atau kepentingan perusahaannya.

Hal yang sedikit berbeda dikemukakan oleh Huala Adolf yang menyatakan bahwa motif yang mendorong suatu perusahaan mengadakan kerja sama patungan dapat bermacam-macam sesuai dengan kepentingan bisnis. Motif utama yang menjadi pertimbangan adalah:

\subsubsection{Faktor politis dan hukum}

Hukum di beberapa negara tidak membolehkan kehadiran suatu perusahaan asing yang dikuasai seluruh kepemilikannya atau melalui bentuk penanaman modal langsung lainnya. Dalam hal ini salah satu cara untuk dapat melakukan usahanya adalah melalui pembentukan usaha patungan (joint venture) dengan perusahaan lokal atau setempat. Persyaratan seperti ini umum dipraktikkan di negara sedang berkembang seperti Indonesia.

\subsubsection{Membagi risiko}

Kadang kala suatu perusahaan merencanakan untuk melakukan suatu proyek atau melakukan penelitian dan pengembangan suatu produk baru. Namun karena dalam proyek tersebut menyangkut investasi yang cukup besar, perusahaan tersebut menjadi enggan untuk melakukan sendiri. Risiko yang harus di tanggung terlalu berat untuk ditanggung sendiri. Dalam keadaan demikian, tersedianya suatu rekanan untuk membagi investasi dan risiko dapat memungkinkan suatu proyek berjalan. 


\subsubsection{Sinergi}

Usaha patungan atau joint venture memungkinkan dua perusahaan menggabungkan keahlian masing-masing dalam membangun sektor usaha tertentu. Dalam hal patungan dengan perusahaan lokal biasanya perusahaan lokal memiliki pengetahuan pemasaran di dalam negerinya seperti memahami sistem ditribusi produknya sendiri sehingga mitra asing memperoleh "keahlian" yang sangat bermanfaat.

\subsubsection{Kompetisi bisnis}

Salah satu tujuan lainnya adalah pertimbangan kompetisi bisnis adalah strategi perusahaan yang utama untuk mempertimbangkan kompetisi bisnis. Strategi ini penting khususnya untuk perusahaan kecil atau menengah. Keputusan untuk masuk ke dunia bisnis adalah masuk ke medan peperangan. Inilah konsep yang dingatkan ahli strategi perang Cina, Sun Tze, yang mengingatkan, salah satu strategi untuk meningkatkan bisnis adalah menjadikan kompetitor bisnis yang kuat sebagai rekanan.

Dalam perkembangannya di Indonesia, pada masa pemerintah Orde Baru di bawah kepemimpinan Presiden Soeharto mewarisi kondisi perekonoman yang kurang baik yang berasal dari Pemerintahan Orde Lama. Pada masa itu, perekonomian Indonesia seakan-akan hendak mengalami keruntuhan karena Indonesia tidak mampu membayar utang luar negeri dan laju inflasi yang tak terhenti. Menghadapi situasi tersebut, pemerintah Orde Baru mengadakan perubahan pendekatan dalam kebijakan ekonomi, antara lain dengan mengundang kembali masuknya modal asing dengan melahirkan Undang-Undang Nomor 1 Tahun 1967 tentang Penanaman Modal Asing. ${ }^{18}$

Untuk menarik modal asing, Undang-Undang Nomor 1 Tahun 1967 menyediakan insentif berupa penggunaan tenaga kerja asing, hak atas tanah, kelonggaran perpajakan, hak transfer dan repatriasi, jaminan hukum

\footnotetext{
${ }^{18}$ Anisah and Wicaksono, Hukum Investasi. Hlm. 206
} 
terhadap kemungkinan nasionalisasi dan penyelesaian sengketa melalui arbitrase internasional. Sebaliknya untuk melindungi kepentingan nasional dari dominasi asing, Undang-Undang Nomor 1 Tahun 1967 memberikan pembatasan-pembatasan terhadap modal asing, antara lain perusahaan asing harus berbentuk badan hukum Indonesia, bidang-bidang usaha tertentu dinyatakan tertutup oleh asing, kewajiban bagi modal asing untuk menggunakan tenaga kerja Indonesia, dan melakukan alih teknologi. Selain itu, penanam modal asing wajib memberikan kesempatan partisipasi bagi modal dalam negeri dan jangka waktu usahanya dibatasi. ${ }^{19}$

Kebutuhan terhadap modal asing pada pertengahan tahun 1960-an mendesak pemerintah untuk mengeluarkan kebijakan penanaman modal asing yang terbuka. Penanaman modal asing tanpa dibebani persyaratanpersyaratan tertentu. Investor dapat menanamkan modalnya dengan penguasaan penuh 100 (seratus) persen saham asing dan tidak ada pembatasan bidang usaha.

Peristiwa Malari pada tahun 1974 mendorong pemerintah untuk menerapkan kebijakan yang restriktif terhadap pemodal asing. Pemerintah kemudian mengenalkan pembatasan bidang usaha dengan menggunakan skala prioritas serta mewajibkan investasi dalam bentuk usaha patungan (joint venture). ${ }^{20}$

Perubahan kebijakan yang sangat fundamental setelah peristiwa Malari adalah keharusan investor asing mendirikan perusahaan (joint venture company). Pemerintah mengharuskan perusahaan penanam modal asing berbentuk perusahaan joint venture karena sebelum peristiwa Malari ketentuan tersebut tidak berlaku memaksa atau imperatif dan tidak diatur secara tegas dalam Undang-Undang Nomor 1 Tahun 1967. Bentuk perusahaan joint venture secara implisit dapat dilihat pada Pasal 23 Undang-Undang Nomor 1 Tahun 1967, sebagai berikut:

\footnotetext{
${ }^{19}$ Supardji, Penanaman Modal Asing Di Indonesia. hlm 34

20 Mahmul Siregar, Perdagangan Internasional Dan Penanaman Modal (Medan: Universitas Sumatera Utara, 2005). Hlm. 1
} 
5.1.1. Dalam bidang-bidang usaha yang terbuka bagi modal asing dapat diadakan kerjasama antara modal asing dengan modal dalam negeri.

5.1.2. Pemerintah menetapkan lebih lanjut bidang-bidang usaha, bentuk-bentuk, dan cara-cara kerjasama antara modal asing dan modal dalam negeri dengan memanfaatkan modal dan keahlian asing dalam bidang ekspor serta produksi barangbarang dan jasa. ${ }^{21}$

Ketentuan tersebut menunjukkan bahwa pembentukan perusahaan joint venture bukan merupakan suatu keharusan dapat dilihat dalam Pasal 27 Undang-Undang Nomor 1 Tahun 1967 yang menyatakan:

(1). Perusahaan yang seluruh modalnya adalah modal asing wajib memberi kesempatan partisipasi bagi modal nasional secara efektif setelah jangka waktu tertentu dan menurut imbangan yang ditetapkan oleh pemerintah.

(2). Jikalau partisipasi tersebut dilakukan dengan penjualan sahamsaham yang telah ada maka hasil penjualan tersebut dapat ditransfer dalam valuta asing dari modal asing yang bersangkutan. ${ }^{22}$

Pada bagian Penjelasan Pasal 8 Undang-Undang Nomor 1 Tahun 1967 ditentukan bahwa untuk memperlancar pelaksanaan pembangunan ekonomi maka pemerintah menentukan bentuk-bentuk kerja sama antara modal asing dan modal nasional yang paling menguntungkan untuk tiap bidang usaha. Bentuk-bentuk kerja sama tersebut dapat berupa kontrak karya, joint venture, atau bentuk lainnya.

Ketentuan Undang-Undang Nomor 1 Tahun 1967 yang menyebutkan terbukanya kerjasama antara modal asing dan modal nasional ditafsirkan sebagai tidak adanya suatu keharusan bagi investor asing untuk mengadakan kerjasama dengan pengusaha Indonesia. Ketentuan tersebut menunjukkan pada dasarnya pemerintah mewajibkan perusahaan penanam modal asing membentuk perusahaan joint venture tetapi hanya mendorong kerja sama tersebut, baik kerja sama pengusaha asing dengan swasta

\footnotetext{
${ }^{21}$ Supardji, Penanaman Modal Asing Di Indonesia. Hlm. 66

${ }^{22}$ Pasal 27 Undang-Undang Nomor 1 Tahun 1967 tentang Penanaman Modal Asing
} 
Indonesia atau pemerintah, dengan memberikan insentif tambahan berupa pembebasan pajak perusahaan dan pajak keuntungan.

Pada tanggal 15 Januari 1974, bertetapan dengan kedatangan Perdana Menteri Kakuci Tanaka, Jakarta dilanda demonstrasi dan kerusuhan (dikenal dengan peristiwa Malari). Kerusuhan tersebut telah menimbulkan pembakaran-pembakaran terutama terhadap mobil-mobil buatan jepang. Berselang satu minggu setelah peristiwa Malari, pemerintah mengumumkan kebijakan baru dalam penanaman asing. Berdasarkan Keputusan Sidang Dewan Stabilitas Ekonomi Nasional yang diselenggarakan tanggal 22 Januari 1974, Penanaman modal asing di Indonesia harus berbentuk joint venture dengan modal nasional.

Keputusan ini dituangkan dalam peraturan pelaksanaan, yaitu Surat Edaran Ketua BPKM No. B-1195/A/BK/X/ 1974. Kebijakan tersebut merupakan kebijakan baru dalam penanaman modal, yaitu:

5.1.1. Penanaman modal asing di Indonesia harus dibentuk joint venture dengan modal nasional;

5.1.2. Penyertaan nasional baik dalam investasi yang lama maupun yang baru harus menjadi $51 \%$ di dalam jangka waktu 10 tahun;

5.1.3. Partner asing harus memenuhi ketentuan pengalihan teknologi kepada karyawan-karyawan Indonesia;

5.1.4. Partisipasi pengusaha pribumi di Indonesia baik dalam penanaman modal asing maupun modal dalam negeri harus ditambah besar.

Ketentuan tersebut di atas ternyata tidak berlaku lama, karena keluarnya Keputusan Ketua BKPM Nomor 5/SK/1987 tentang Persyaratan Pemilikan Saham Nasional dalam Perusahaan Penanam Modal Asing. Dalam ketentuan ini perusahaan penanam modal asing harus berpatungan dengan penyertaan modal nasional minimal 20\% dan meningkatkan menjadi minimal $51 \%$ dalam waktu 15 Tahun. ${ }^{23}$ Berlokasi di kawasan

${ }^{23}$ Keputusan Ketua BKPM No. 5/SK/1987 tentang Persyaratan Kepemilikan Saham Nasional dalam Perusahaan Penanaman Modal Asing. 
berikat dan mengekspor $100 \%$ hasil produksi dapat didirikan dengan penyertaan modal nasional 5\% atau lebih tanpa keharusan peningkatan saham nasional.

Kebijakan di atas kemudian diubah pada tahun 1989 dengan Keputusan Ketua BKPM Nomor 08/SK/1989 tertanggal 5 Mei 1989 yang menyatakan bahwa perusahaan penanam modal asing yang menjual sahamnya minimal 20\% melalui pasar modal sebagai saham atas nama sehingga minimal 45\% sahamnya dimiliki oleh negara dan/atau swasta nasional diberi perlakuan yang sama seperti perusahaan penanam modal dalam negeri sehingga tidak diwajibkan meningkatkan saham nasionalnya menjadi sekurang-kurangnya $51 \%$ dengan pembentukan kawasan berikat di Pulau Batam. Pada tahun 1989, berdasarkan Keputusan Ketua BKPM ditetapkan bahwa perusahaan penanam modal asing dapat didirikan dengan penyertaan saham seluruhnya $100 \%$ dimiliki oleh asing, dengan syarat berlokasi di Pulau Batam, 100\% hasil produksinya diekspor, dalam waktu lima tahun sesudah produksi komersil paling sedikit 5\% sahamnya dijual kepada mitra usaha Indonesia, tanpa harus peningkatan saham nasional.

Kemudian dalam Peraturan Pemerintah Nomor 17 tahun 1992 juncto Peraturan Pemerintah Nomor 7 Tahun 1993 tentang Pemilikan Modal Saham Perusahaan Penanam Modal Asing, yaitu dalam Pasal 2 Peraturan Pemerintah Nomor 17 Tahun 1992 ditentukan bahwa perusahaan yang didirikan dalam rangka penanaman modal asing, selanjutnya disebut Penanam Modal Asing, pada dasarnya berbentuk usaha patungan dengan persyaratan bahwa pemilik modal saham perserta Indonesia dalam perusahaan patungan tersebut sekurang-kurangnya 20\% (dua puluh persen) dari seluruh nilai modal saham perusahaan pada waktu pendirian perusahaan patungan dan ditingkatkan menjadi sekurang-kurangnya $51 \%$ dalam waktu 20 tahun terhitung sejak perusahaan berproduksi secara komersial sebagaimana yang tercantum dalam izin usahanya. ${ }^{24}$

${ }^{24}$ Supardji, Penanaman Modal Asing Di Indonesia. Hlm. 211 
Lebih lanjut lagi berdasarkan Pasal 2 Peraturan Pemerintah Nomor 20 Tahun 1994 tentang Pemilikan Saham dalam Perusahaan yang didirikan dalam Rangka Penanaman Modal Asing, ditentukan bahwa penanaman modal asing dapat dilakukan dalam bentuk:

5.1.1. Patungan antara modal asing dengan modal yang dimiliki warga negara Indonesia dan atau badan hukum Indonesia;

5.1.2. Langsung dalam artian seluruh modal dimiliki oleh warga negara dan/atau badan hukum asing.

Selanjutnya Pasal 6 Peraturan Pemerintah Nomor 20 Tahun 1994 mengatur bahwa komposisi saham peserta Indonesia dalam perusahaan joint venture sekurang-kurangnya 5\% dari seluruh modal yang disetor perusahaan pada saat pendirian, sedangkan warga Negara dan/atau badan hukum asing sebesar 95\%. Ini berarti bahwa Penanam Modal Asing mempunyai saham mayoritas dalam perusahaan joint venture tersebut, sedangkan peserta Indonesia hanya mempunyai saham minoritas.

Selanjutnya, setelah masa reformasi dimulailah babak baru penanaman modal di Indonesia dengan diundangkannya Undang-Undang Nomor 25 Tahun 2007. Berdasarkan Undang-Undang Nomor 25 Tahun 2007, penanaman modal asing dapat melakukan usaha di wilayah negara Republik Indonesia yang dilakukan oleh Penanam Modal Asing, baik menggunakan modal asing sepenuhnya maupun yang berpatungan dengan penanaman modal asing. ${ }^{25}$

Indonesia dewasa ini mempunyai peraturan perundang-undangan yang mengatur bentuk usaha patungan (joint venture) berbentuk Equity Joint Venture. Ketentuan mengenai Daftar Negatif Investasi (DN) diatur dalam Peraturan Presiden Nomor 44 Tahun 2016 tentang Daftar Bidang Usaha Yang Tertutup dan Bidang Usaha Yang Terbuka Dengan Persyaratan di Bidang Penanaman Modal yang berkaitan dengan bidang usaha yang terbuka dengan persyaratan yang salah satunya terkait dengan

\footnotetext{
${ }^{25}$ Pasal 1 angka 3 Undang-Undang No. 25 Tahun 2007 tentang Penanaman Modal
} 
batasan kepemilikan modal asing. ${ }^{26}$ Dengan demikian secara tidak langsung ketentuan tersebut mewajibkan penanam modal asing untuk bermitra dengan penanam modal dalam negeri dengan membentuk joint venture enterprise atau equity joint venture.

Kegiatan penanaman modal asing langsung di Indonesia harus dijalankan melalui perusahaan berbadan hukum Indonesia dan berkedudukan di Indonesia, sebagaimana ditetapkan dalam Pasal 5 ayat (2) Undang-Undang Nomor 25 Tahun 2007 tentang Penanaman Modal, yakni dalam bentuk perseroan terbatas. Berkaitan dengan hal ini, badan usaha yang berbentuk perseroan terbatas yang akan menanamkan modal di Indonesia harus mengikuti ketentuan yang tercantum dalam UndangUndang Nomor 40 Tahun 2007 tentang Perseroan Terbatas dinyatakan bahwa perseroan terbatas adalah badan hukum yang didirikan berdasarkan perjanjian. Dengan demikian, terdapat dua perjanjian yang menjadi landasan pembentukan perusahaan patungan (joint venture company), yakni joint venture agreement dan anggaran dasar (article of asscociation).

Joint venture agreement yang dibuat oleh investor asing dan investor nasional akhirnya bermuara pada pendirian joint venture company, sehingga joint venture company dapat dikatakan berdiri atau lahir atas dasar perjanjian. Asas kebebasan berkontrak (freedom of contract) dalam hukum perjanjian memungkinkan hal itu terjadi, sepanjang tidak melanggar ketentuan hukum, kepatutan dan kesusilan yang baik. Asas kebebasan berkontrak (freedom of contract) sebagai asas yang berlaku universial dalam hukum perjanjian, memberikan keleluasaan kepada para pihak yang terlibat dalam perjanjian, untuk menentukan isi perjanjiannya. Tidak hanya itu, sebuah perjanjian yang dibuat secara sah, berlaku sebagai Undang-Undang bagi mereka yang membuatnya (Pasal 1338 ayat (1) KUHPerdata) serta memiliki kekuatan mengikat (pacta sunt servanda) terhadap para pihak yang membuatnya.

\footnotetext{
${ }^{26}$ Pasal 2 ayat (2) Peraturan Presiden No.44 Tahun 2016. Daftar Bidang Usaha Yang Tertutup dan Bidang Usaha Yang Terbuka Dengan Persyaratan di Bidang Penanaman Modal
} 
Joint venture agreement yang dijadikan salah satu syarat dalam penanaman modal asing oleh Badan Koordinasi Penanaman Modal (BKPM) digunakan sebagai dasar dibentukanya joint venture company. Artinya joint venture company tunduk kepada hukum perjanjian. Namun dalam Pasal 5 ayat (2) UUPM, joint venture company harus berbentuk perseroan terbatas berdasarkan hukum Indonesia. sehingga dapat dikatakan bahwa joint venture company tunduk kepada hukum perusahaan dalam hal ini Undang-Undang Nomor 40 Tahun 2007 Tentang Perseroan Terbatas.

Undang-Undang Nomor 25 Tahun 2007 tentang Penanaman Modal dalam Pasal 5 ayat (2) menentukan bahwa penanam modal asing di Indonesia harus dalam bentuk perseroan terbatas (limited liability company, naamloze vennotschap). Perseroan terbatas menurut hukum Indonesia adalah badan hukum yang merupakan persekutuan modal, didirikan berdasarkan perjanjian, yang melakukan kegiatan usaha dengan modal dasar yang seluruhnya terbagi dalam saham dan memenuhi persyaratan yang ditetapkan dalam Peraturan Perundang-Undangan. ${ }^{27}$

Perseroan terbatas merupakan bentuk usaha kegiatan ekonomi yang paling disukai saat ini, disamping karena pertanggungjawabannya yang bersifat terbatas, perseroan terbatas juga memberikan kemudahan bagi pemilik (pemegang saham) untuk mengalihkan perusahaannya kepada setiap orang dengan menjual seluruh saham yang dimilikinya pada perusahaan tersebut. kata "perseroan" menunjuk kepada modal yang terdiri atas sero (saham), sedangkan kata "terbatas" menunjuk kepada tanggung jawab pemegang saham yang tidak melibihi nilai nominal saham yang diambil bagian dan dimiliki. ${ }^{28}$ Dikarenakan oleh hal-hal tersebut, maka tepat apabila Undang-Undang mengatur bahwa perseroan terbatas merupakan wadah bagi penanaman modal asing di Indonesia.

Berdasarkan hal tersebut, maka suatu perusahaan penanam modal asing selain tunduk pada Undang-Undang Nomor 25 Tahun 2007 tentang Penanaman Modal, juga harus tunduk kepada Undang-Undang Nomor 40

\footnotetext{
${ }^{27}$ Pasal 1 angka 1 Undang-Undang Nomor 40 Tahun 2007 Tentang Perseroan Terbatas.

28 Ahmad Yani and Gunawan Widjaja, Perseroan Terbatas (Jakarta: Raja Grafindo Persada, 2003). Hlm. 1
} 
Tahun 2007 tentang Perseroan Terbatas beserta seluruh peraturan pelaksanaanya. Dalam Pasal 7 ayat (1) Undang-Undang Nomor 40 Tahun 2007 tentang Perseroan Terbatas, menjelaskan bahwa:

"Perseroan didirikan oleh 2 orang atau lebih dengan akta notaris yang dibuat dalam bahasa Indonesia". ${ }^{29}$

Menurut Rudhi Prasetya isi dari joint venture agreement ini sangat lengkap, bahkan lebih lengkap dari anggaran dasar (articles of association) dari perusahaan yang dibentuk. Sehingga tidak semua ketentuan-ketentuan yang disepakati dalam joint venture agreement dapat dimasukkan ke dalam akta pendirian perusahaan, karena akta pendirian perusahaan yang dibuat oleh Notaris biasanya memiliki standar format yang disudah ditetapkan. Penetapan standar tersebut bertujuan untuk mempermudah proses klasifikasi kelengkapan dokumen yang akan diajukan kepada Departemen Hukum dan HAM. ${ }^{30}$

Undang-Undang Nomor 25 Tahun 2007 telah mengatur secara umum bahwa investor asing dapat menanamkan modalnya dengan cara:

5.1.1. Investor asing menanamkan modal asing $100 \%$ atau seluruhnya, atau

5.1.2. Investor asing bekerja sama dengan penanam modal dalam negeri

Tetapi pengaturan tersebut tidak berlaku secara imperatif, pengaturan secara imperatif besaran investasi modal asing diatur lebih lanjut didalam Peraturan Presiden Nomor 44 Tahun 2016 tentang Daftar Bidang Usaha yang Tertutup Untuk Penanaman Modal. ${ }^{31}$ Batasan kepemilikan modal penanam modal asing adalah bervariasi antara $49 \%$ sampai dengan 95\% Untuk bidang investasi mengenai Pemanfaatan Sumber Daya Genetik Pertanian misalnya besarnya modal bagi penanam modal asing adalah maksimum sebesar 49\%, sedangkan untuk bidang

${ }^{29}$ Pasal 7 ayat (1) Undang-Undang Nomor 40 Tahun 2007 tentang Perseroan Terbatas.

${ }^{30}$ Rudhi Prasetya, Kedudukan Mandiri Perseroan Terbatas (Bandung: PT. Citra Aditya Bakti, 2001). Hlm 167.

${ }^{31}$ Peraturan Presiden Nomor 77 Tahun 2007 tentang Daftar Bidang Usaha yang Tertutup dan Bidang Usaha Yang Terbuka dengan Persyaratan di Bidang Penanaman Modal. 
usaha pengusahaan jalan tol jumlah pemilikan modal bagi penanam modal asing adalah maksimul sebesar $95 \% .^{32}$

\subsection{Kendala dan Kritik dalam Pelaksanaan Joint Venture di Indonesia}

Berbagai permasalahan yang timbul berkaitan dengan kerjasama patungan (joint venture) yang dilakukan antara modal asing dan nasional, dimulai sejak permulaan suatu usaha kerja sama sampai pada pengelolaan perusahaan. Adapun kendala yang dihadapi oleh pemodal dalam negeri dengan penanam modal asing dalam bentuk joint venture dilihat dari tiga aspek antara lain politik, hukum, dan ekonomi. ${ }^{33}$

5.2.1. Dilihat dari segi politik

Penanaman modal asing dapat mengeruk keuntungan melalui praktik-praktik yang tidak wajar seperti transfer pricing, penyeludupan pajak, dan penguasaan pasar dengan monopoli. $^{34}$

5.2.2. Dilihat dari segi hukum

Perlu dipahami oleh kedua belah pihak bahwa terdapat persinggungan dua sistem hukum yang berbeda dengan sifat karakter maupun prinsipnya. Masalah lainya yaitu pilihan hukum (choice of law), yakni hukum mana yang digunakan untuk mendasari perjanjian kerja sama tersebut agar dalam sengketa nantinya dapat ditentukan posisi hukum kedua belah pihak.

Selanjutnya persamalahan pada bentuk perusahaan joint venture (joint venture company) yang diatur Pada Pasal 5 ayat (2) yang menyatakan bahwa Penanaman modal Asing

${ }^{32}$ Binoto Nadapdap, Hukum Perseroan Terbatas Berdasarkan Undang-Undang No.40 Tahun 2007 (Jakarta: Penerbit Aksara, 2013). Hlm. 79. Hlm. 218

${ }^{33}$ Aminuddin Ilmar, Hukum Penanaman Modal Di Indonesia (Jakarta: Kencana, 2007).

${ }^{34}$ Transfer Pricing merupakan transaksi barang dan jasa antara beberapa divisi pada suatu kelompok usaha dengan harga tidak wajar, dapat dengan menaikkan (mark up) atau menurunkan harga (mark down), kebanyakan dilakukan oleh perusahaan global (multi-national Enterprise). Tujuannya adalah untuk mengakali jumlah profit sehingga pembayar pajak dan pembagian dividen menjadi rendah; dan menggelembungkan profit untuk memoles (window dressing) laporan keuangan. 
wajib dalam bentuk perseroan terbatas berdasarkan hukum Indonesia dan berkedudukan di dalam wilayah negara Republik Indonesia, kecuali ditentukan lain oleh UndangUndang. Hal ini membatasi bahwa perusahaan joint venture dalam penanaman modal asing hanya dalam bentuk Perseroan Terbatas. Padahal jika dilihat secara yuridis normatif banyak bentuk perusahaan yang ada di Indonesia salah satunya adalah koperasi.

Di Indonesia koperasi dinilai sebagai bentuk perusahaan yang paling tepat dalam pewujudan semangat konstitusi Indonesia, seperti dinyatakan pada pasal 33 ayat (1) Bab XIV tentang perekonomian Nasional dan Kesejahteraan sosial bahwa perekonomian disusun sebagai usaha bersama berdasar atas asas kekeluargaan, menurut pendapat Moh Hatta bahwa koperasilah bentuk perusahaan yang paling tepat mencerminkan konsitusi Indonesia karena mempunyai dasar atas asas kekeluargaan.

5.2.3. Dilihat dari segi ekonomi, perimbangan kedua belah pihak, pembagian keuntungan, kerja (managament), masalah alih teknologi serta Indonesianisasi. ${ }^{35}$

Selanjutnya risiko potensial dalam kerja sama patungan antara lain:

5.2.1. Perbedaan budaya antara pihak-pihak dari berbagai yuridiksi dapat menyebabkan kesalahpahaman dan inefiensi yang signifikan;

5.2.2. Ketidaksesuaian atau perbedaan strategi dapat mengakibatkan kerugian dan kegagalan untuk mencapai tujuan bisnis secara keseluruhan;

5.2.3. Masalah operasional, apakah akibat perbedaan strategis, masalah produksi, pengendalian manajamen atau sebaliknya, dapat membatasi keefektifan usaha pantungan tersebut;

\footnotetext{
${ }^{35}$ Ilmar, Hukum Penanaman Modal Di Indonesia. Hlm. 109
} 
5.2.4. Kurangnya kepercayaan di antara para pihak dapat membatasi kerjasama patungan;

5.2.5. Proses pembuatan keputusan dan penyelesaian sengketa dapat berlangsung lama dan mahal, tergantung pada mekanisme apa yang disepakati dalam dokumentasi usaha patungan dan praktik apa yang telah berkembang selama masa usaha bersama langsung;

5.2.6. Perjanjian jasa dan kontribusi (service and contribution agreements), sering kali dipandang sebagai tambahan dalam hubungan kerja sama yang dapat menciptakan ketergantungan dari usaha patungan kepada pihak tertentu, walaupun di dalam perusahaan kerjasama patungan (equity joint venture) dapat dibentuk dengan tujuan memberikan independensi kepada para pihak yang mendirikannya; dan

5.2.7. Mengakhiri kerja sama patungan dapat mengeluarkan biaya yang masalah dan sulit.

Untuk itu, kerja sama patungan dapat berjalan dengan baik apabila terdapat pengaturan penanaman modal yang tepat dan dilaksanakan dalam keadaan tertentu, misalnya pengaturan penanaman modal yang dapat mereduksi dan mengidentifikasi potensi kerugian dan risiko, dengan pengelolaan penanaman modal secara baik dan penuh kehatihatian, dan perencanaan yang matang dan dokumentasi yang baik dan sesuai peraturan yang berlaku.

Hal lain yang dapat dilakukan oleh para pihak untuk meminimalisasikan risiko atau kendala yang mungkin dihadapi pada saat pelaksanaan kerja sama patungan adalah melakukan tindakan preventif. Pada awal pembentukan kerja sama patungan, para pihak sebaiknya menentukan kesepakatan-kesepakatan yang sesuai untuk mengatur hubungan mereka berdasarkan tujuan dan strategi masing-masing. Sebagai contoh, disamping pilihan untuk membentuk perusahaan kerja sama patungan (equity joint venture), para pihak harus 
mempertimbangkan apakah jenis pengaturan berikut sesuai dengan tujuan komersial masing-masing, yaitu: ${ }^{36}$

5.2.1. Perjanjian pasokan untuk barang atau jasa;

5.2.2. Perjanjian distribusi atau agensi;

5.2.3. Perjanjian lisensi atau waralaba;

5.2.4. Perjanjian Penelitian dan pengembangkan atau kerjasama;

5.2.5. Akusisi $100 \%$ atau

5.2.6. Pembentuk anak perusahaan yang sepenuhnya dimiliki tanpa partisipasi dari pihak lain.

\section{Kesimpulan}

Indonesia dewasa ini mempunyai peraturan perundang-undangan yang mengatur bentuk usaha patungan (joint venture) berbentuk Equity Joint Venture. ketentuan mengenai Daftar Negatif Investasi (DN) diatur dalam Peraturan Presiden Nomor 44 Tahun 2016 yang berkaitan dengan bidang usaha yang terbuka dengan persyaratan, salah satunya mensyaratkan terkait dengan batasan kepemilikan modal asing. Dengan demikian secara tidak langsung ketentuan tersebut mewajibkan penanam modal asing untuk bermitra dengan penanam modal dalam negeri dengan membentuk joint venture enterprise atau equity joint venture.

Kegiatan penanaman modal asing langsung di Indonesia harus dijalankan melalui perusahaan berbadan hukum Indonesia dan berkedudukan di Indonesia, sebagaimana ditetapkan dalam Pasal 5 ayat (2) Undang-Undang Nomor 25 Tahun 2007 tentang Penanaman Modal, yakni dalam bentuk perseroan terbatas. Berkaitan dengan hal ini, badan usaha yang berbentuk perseroan terbatas yang akan menanamkan modal di Indonesia harus

\footnotetext{
${ }^{36}$ Beberapa karakteristik darar dari kerjasama patungan adalah berbentuk kontrak kerja patungan, atau pembentukan anak-anak perusahaan yang kepemilikan saham sepenuhnya oleh induk perusahaan di negara asal penanam modal (greenfild). Dalam situasi ketika para perserta kerja sama patungan percaya bahwa kontrak kerja sama patungan yang disepakati tersebut menguntungkan, seringkali potensi masalah ada pada regulasi setempat. Regulasi itu dapat mempengaruhi hubungan kontraktual para pihak, yang justru oleh pihak-pihak itu sendiri tidak dimaksudkan demikian, untuk itu, calon peserta kerja sama patungan harus selalu mempertimbangkan kemungkinan munculnya dampak yang berasal dari regulasi setempat sejak awal atau pada tahap perencanaan kontrak.
} 
mengikuti ketentuan yang tercantum dalam Undang-Undang Nomor 40 Tahun 2007 tentang Perseroan Terbatas dinyatakan bahwa perseroan terbatas adalah badan hukum yang didirikan berdasarkan perjanjian. Dengan demikian, terdapat dua perjanjian yang menjadi landasan pembentukan perusahaan patungan (joint venture company), yakni joint venture agreement dan anggaran dasar (article of asscociation).

Kendala yang dihadapi oleh pemodal dalam negeri dengan penanam modal asing dalam bentuk joint venture dilihat dari tiga aspek yaitu : Aspek politik, penanaman modal asing dapat mengeruk keuntungan melalui praktikpraktik yang tidak wajar seperti transfer pricing, penyeludupan pajak dan penguasaan pasar dengan monopoli. Kemudian aspek hukum perlu dipahami oleh kedua belah pihak bahwa terdapat persinggungan dua sistem hukum yang berbeda dengan sifat karakter maupun prinsipnya. Masalah lainya yaitu pilihan hukum (choice of law), yakni hukum mana yang digunakan untuk mendasari perjanjian kerja sama tersebut agar dalam sengketa nantinya dapat ditentukan posisi hukum kedua belah pihak dan dilihat dari aspek ekonomi, perimbangan kedua belah pihak, pembagian keuntungan, kerja (managament), masalah alih teknologi serta Indonesianisasi. 


\section{DAFTAR PUSTAKA}

\section{Buku}

Abdurrachman, A. Ensiklopedia Tentang Konsep Ekonomi Keuangan Perdagangan. Jakarta: Pradnya Paramita, 1992.

Anisah, Siti, and Lucky Surya Wicaksono. Hukum Investasi. Yogyakarta: UII Press, 2017.

Bandur, and Agustinus. Penelitian Kualitatif Metodologi, Desain Dan Teknik Analisi Data Dengan NVIVO10. Jakarta: Mitra Wacana Media, 2014.

Head, John W. Pengantar Umum Hukum Ekonomi. Jakarta: Proyek Elips, 1997.

HS, Salim, and Budi Sutrisno. Hukum Investasi Di Indonesia. Jakarta: Raja Grafindo Persada, 2012.

Ilmar, Aminuddin. Hukum Penanaman Modal Di Indonesia. Jakarta: Kencana, 2007.

Nadapdap, Binoto. Hukum Perseroan Terbatas Berdasarkan Undang-Undang No.40 Tahun 2007. Jakarta: Penerbit Aksara, 2013.

Nasution, Asmin. Transparansi Dalam Penanaman Modal. Medan: Pustaka Bangsa Press, 2008.

ND, Mukti Fajar, and Yulianto Achmad. Dualisme Penelitian Hukum Normatif \& Empiris. Yogyakarta: Pustaka Pelajar, 2010.

Prasetya, Rudhi. Kedudukan Mandiri Perseroan Terbatas. Bandung: PT. Citra Aditya Bakti, 2001.

Rajaguguk, Erman. Indonesianisasi Saham. Jakarta: Bumi Aksara, 1985.

Siregar, Mahmul. Perdagangan Internasional Dan Penanaman Modal. Medan: Universitas Sumatera Utara, 2005.

Sulistiyono, Adi, and Muhammad Rustamaji. Hukum Ekonomi Sebagai Panglima,. Sidoarjo: Mas Media Buana Pustaka, 2009.

Sunny, Ismail. Tinjauan Dan Pembahasan Undang-Undang Penanaman Modal Asing Dan Kredit Luar Negeri. Jakarta: Pradnya Paramita, 1967.

Supardji. Penanaman Modal Asing Di Indonesia. Jakarta: Universitas Al- 
Azhar Indonesia, 2008.

Yani, Ahmad, and Gunawan Widjaja. Perseroan Terbatas. Jakarta: Raja Grafindo Persada, 2003.

\section{Artikel Jurnal}

Syahyu, Yulianto. "Pertumbuhan Investasi Asing Di Kepalauan Batam: Antara Dualisme Kemimpinan Dan Ketidakpastian Hukum.” Jurnal Hukum Bisnis 22, no. 5 (2003).

Yulianto, Ahmad. "Peranana Multilateral Investment Guarantee Agency (MIGA) Dalam Kegiatan Investasi.” Jurnal Hukum Bisnis 22, no. 5 (2003).

\section{Peraturan Perundang-Undangan}

Undang-Undang Nomor 1 Tahun 1967 tentang Penanaman Modal Asing Keputusan Ketua BKPM No. 5/SK/1987 tentang Persyaratan Kepemilikan Saham Nasional dalam Perusahaan Penanaman Modal Asing.

Undang-Undang Nomor 25 Tahun 2007 tentang Penanaman Modal Peraturan Presiden Nomor 44 Tahun 2016 tentang Daftar Bidang Usaha Yang Tertutup dan Bidang Usaha yang Terbuka Dengan Persyaratan Di Bidang Penanaman Modal Undang-Undang Nomor 40 Tahun 2007 Tentang Perseroan Terbatas. Peraturan Presiden Nomor 77 Tahun 2007 tentang Daftar Bidang Usaha yang Tertutup dan Bidang Usaha Yang Terbuka dengan Persyaratan di Bidang Penanaman Modal.

\section{Media Online}

www.bakermckenzie.com, di akses pada tanggal 27 Juli 2018 